\title{
Evidence of a uteroglobin-like protein in epithelial cells of reproductive and non-reproductive tissues of the rabbit
}

\author{
Ingrid G. Noske* and Mitzi Gooding \\ Department of Anatomy, Downing Street, Cambridge, U.K. and \\ *Max-Planck Institute of Biochemistry, 8033 Martinsried, \\ Federal Republic of Germany
}

\begin{abstract}
Summary. An antiserum raised in a goat to a uteroglobin-like protein isolated from uterine fluid of oestrous rabbits was used in an immune fluorescence test to localize an antigen present in the reproductive tract of oestrous and pseudopregnant rabbits and mammary gland tissue. The antigen was also present in the vas deferens and seminal vesicle, but not in testis. Non-reproductive tissues, such as lung, small intestine, bladder and thyroid showed specific fluorescent staining which was eliminated or significantly reduced by absorption of the antiserum with a purified uteroglobin preparation.
\end{abstract}

\section{Introduction}

The presence of a specific uterine protein during early pregnancy in the rabbit was reported by Schwick (1965), Beier (1968) and Krishnan \& Daniel (1967). This protein, termed uteroglobin or blastokinin, is present in increasing amounts as pregnancy progresses until Days 6-7, and then it decreases. Johnson (1972) and Kirchner $(1972,1976)$ have used an antiserum specific to uteroglobin and reported specific fluorescent staining patterns in uterine tissue sections of pregnant and oestrous rabbits. Kay \& Feigelson (1972) have described a protein in the rabbit oviduct that was estimated to have a molecular weight of 18000 , similar to that of the protein in the uterus of pregnant animals. Furthermore, they reported that the protein in the oviduct exhibits a cone-like structure upon electrophoretic destaining in the disc-gel-electrophoresis system. Subsequently, Goswami \& Feigelson (1974) recorded the presence of a protein with the same characteristics in the oestrous rabbit uterus. Noske \& Feigelson (1976) and Feigelson, Noske, Goswami \& Kay (1977) obtained an antiserum that was monospecific by immunodiffusion criteria and showed that uteroglobin and the coneforming protein were immunologically indistinguishable. By using this antiserum, we have now attempted to localize the cone-forming protein in tissue cells to test whether its distribution also corresponds to that of uteroglobin.

\section{Materials and Methods}

To prepare the antiserum, fluid was collected from the ligated uterine horns of oestrous rabbits, concentrated about 10-fold and fractionated on Sephadex G-100 columns, with 0.05 M-sodium phosphate buffer, $\mathrm{pH} 6.9$, as the elution medium. The fractions that contained the uteroglobin-like protein were reconcentrated on the Amicon filter system by using a UM 05 membrane. Aliquots were analysed on a $7.5 \%$ polyacrylamide separating gel, as described by Davis (1964). The region containing the antigen was identified by comparison with a stained reference gel, excised and emulsified with complete Freund's adjuvant before injection into a goat. After two injections an antiserum was obtained that formed a single precipitin line in the Ouchterlony double-immunodiffusion system with unfractionated uterine fluid and with the fraction obtained from Sephadex G-100 elution profiles (Noske \& Feigelson, 1976). For some tests the antiserum was further absorbed with four 20- $\mu 1$ aliquots of a preparation of uteroglobin purified by G-200, G-100 and G-75 Sephadex gel filtration. 
The preparation was electrophoretically and immunologically pure (M. H. Johnson, personal communication). For the indirect immune fluorescence studies, the immunoglobulin fraction of the antiserum to the uteroglobin-like protein was absorbed with freshly homogenized tissues of rabbit spleen, heart and kidney. Thereafter, the antiserum preparation was used at a dilution of $1: 8$ in phosphate-buffered saline (PBS), pH 7·1. The fluorescein-conjugated rabbit antiserum to goat IgG (Miles Laboratories Ltd, Slough, England) was absorbed once with $50 \mathrm{mg}$ liver powder $/ \mathrm{ml}$ and twice with homogenates of liver, and was used at a dilution of $1: 20$.

Histological sections of tissues from 2-3 pseudopregnant does and 2-3 male rabbits were prepared as described by Johnson (1972). The dewaxed and washed tissue sections were incubated for $20 \mathrm{~min}$ at $30^{\circ} \mathrm{C}$ with the antiserum to the uteroglobin-like protein. Control sections were treated with PBS or uteroglobin-absorbed antiserum. The incubation was followed by washing for $10 \mathrm{~min}$ in PBS, incubation with conjugate for $20 \mathrm{~min}$, and then by another 10-min washing. Thereafter, the sections were embedded in glycerol-PBS, pH 7.1 (3:1 v/v), for observation under epifluorescence illumination with a Zeiss microscope.

\section{Results}

Specific fluorescence was located in tissues of the uterus, oviduct, ovary, mammary gland, lung (female and male), small intestine, vas deferens, seminal vesicle, bladder and thyroid; it was absent from tissues of the testis, kidney and spleen. Liver sections could not be scored because of their autoimmunofluorescence. The distribution and the amount of antigen present differed in the various organs tested. In the oviduct fluorescence, when present, was found mainly inside the cytoplasm of the epithelial cells, but depended on the region of the oviduct. Oviduct sections taken close to the ovarian end showed fluorescence on the surface of the epithelium only, whereas sections taken closer to the uterine isthmus show fluorescence in the whole cytoplasm (Pl. 1, Fig. 1). This differential staining could represent differential secretion or absorption of the uteroglobin-like protein by epithelial cells of the oviduct. Specific fluorescence was present in the glands of the uterus of oestrous rabbits and in epithelial cells or on the uterine surface of pseudopregnant rabbits. In pseudopregnancy fluorescence within the epithelial cells was observed up to Day $6 \frac{1}{2}$ (PI. 1, Fig. 2), but sections of uteri taken from does at Day $11 \frac{1}{2}$ showed that the fluorescence was present only on the surface of the endometrium and not within the epithelial cells. Ovarian tissue, which gives a single precipitin line in the Ouchterlony double-immunodiffusion test (Noske \& Feigelson, 1976; Feigelson et al., 1977), showed faint specific fluorescence which was not easily distinguishable from the liver control in which considerable non-specific fluorescence occurred.

Sections of mammary gland tissue showed fluorescence in the outer part of the epithelial cells. Bladder tissue exhibited specific fluorescence on the surface of the epithelial cells: it is possible that this represented protein antigen excreted into the bladder, thus implying low blood levels of free uteroglobin-like material. In sections of the vas deferens (Pl. 1, Fig. 3) and the seminal vesicle (Pl. 1, Fig. 4), the whole cytoplasm of the epithelial cells but not the nuclear region was filled with fluorescence staining. In contrast, sections of the testis did not react with the antibody and there was

\section{EXPLANATION OF PLATE}

Immunofiuorescence patterns obtained with a uteroglobin-like antigen in various reproductive and nonreproductive tissues of the female and male rabbit.

Fig. 1. Specific fluorescence located in the whole cytoplasm of epithelial cells in the oviduct.

Fig. 2. Fluorescence in the uterus of the oestrous rabbit is located at the apex of the luminal cells.

Fig. 3. Epithelial cells of the vas deferens show specific fluorescence. No fluorescence is seen in the stroma.

Fig. 4. The seminal vesicle epithelial cells stain like those of the vas deferens. Fluorescence is present in the whole cytoplasm.

Fig. 5. Fluorescence staining pattern in the bronchi of rabbit lung is comparable to that in the endometrium (Fig. 2). 
PLATE 1
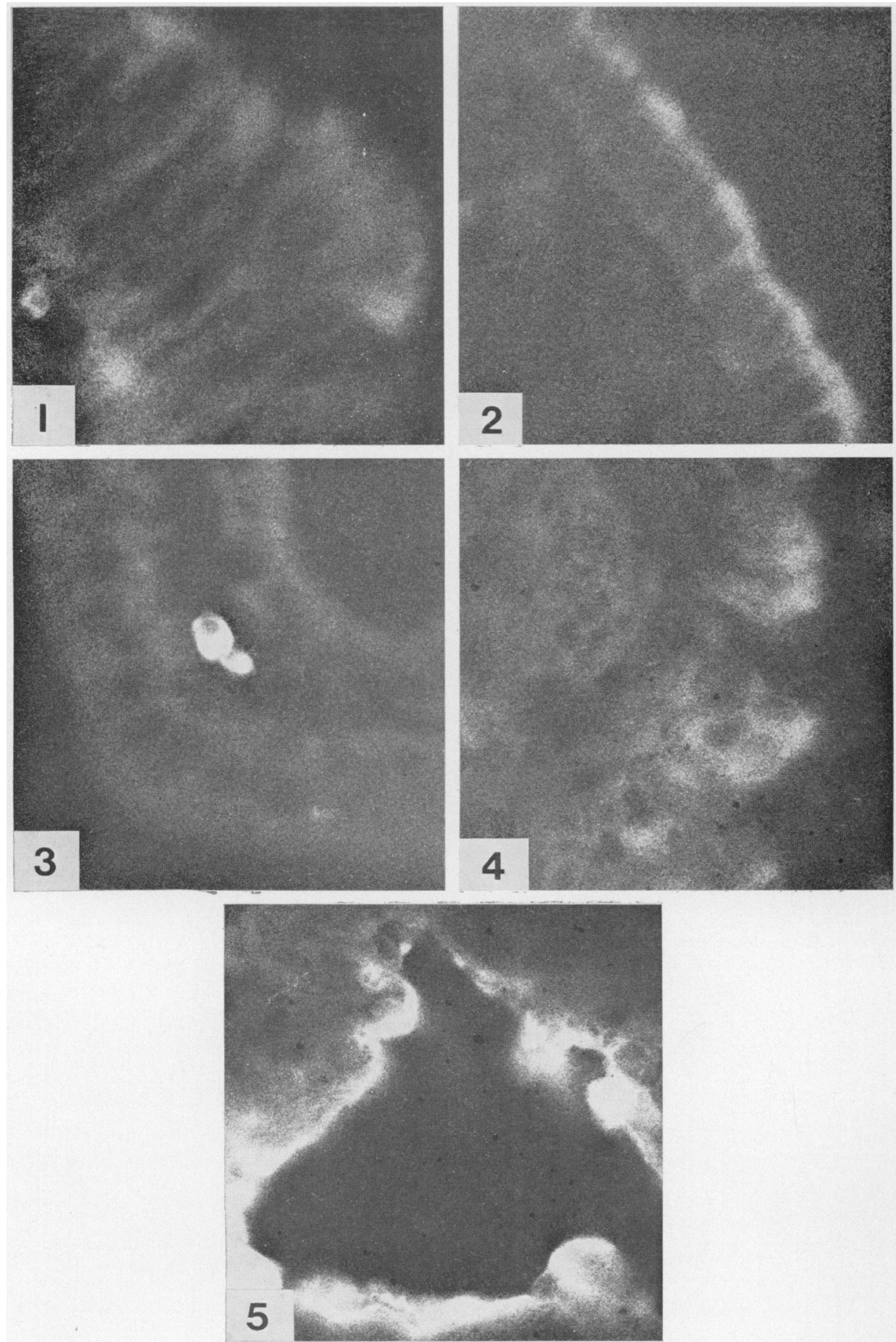

(Facing p. 194) 
no precipitin line in the Ouchterlony double-immunodiffusion test. Lung tissue sections of female and male rabbits showed fluorescence in the outer parts of the cytoplasm toward the alveolar lumen of the bronchi (Pl. 1, Fig. 5). Similarly the epithelial region of the small intestines showed surface fluorescence staining, comparable to that of uterine tissue on Day $11 \frac{1}{2}$ post coitum and of bladder tissue. Thyroid acinar cells also stained luminally. In all glandular tissue studied, the stroma showed no specific fluorescence. Absorption of the antiserum to the uteroglobin-like protein with purified uteroglobin removed or markedly reduced the specific fluorescence compared to that observed in all positive sections, indicating that the unknown antigen is immunologically identical or sufficiently similar to uteroglobin to cross-react with it.

\section{Discussion}

The fluorescent staining pattern which we observed for uterine tissue of oestrous and pseudopregnant rabbits by using the specific antiserum to the isolated uteroglobin-like protein of oestrous rabbit uterine fluid is comparable to the staining pattern reported by Johnson (1972), who used an antiserum to unfractionated uterine fluid of 5-day pregnant rabbits and made it specific to uteroglobin/blastokinin by absorption with various rabbit tissues.

The widespread occurrence of an antigen which shows a distribution in uterine tissue identical to that of uteroglobin and an immunological cross-reaction with uteroglobin, as judged by precipitation and absorption, suggests that the uteroglobin molecule, or some part of it, might have a wider significance in secretory epithelia than has hitherto been suspected. Although the function of uteroglobin in the uterus is not agreed, it is able to bind steroid hormones (Urzua, Stambaugh, Flickinger \& Mastroianni, 1970; Arthur, Cowan \& Daniel, 1972; Beato \& Baier, 1975; Beato, Arnemann \& Voss, 1977). Most of the tissues in which the uteroglobin-like protein has been detected within cells by immunofluorescence are also targets for steroid hormones. Uteroglobin is composed of subunits (McGaughey \& Murray, 1972; Murray, McGaughey \& Yarus, 1972; Nieto, Ponstingl \& Beato, 1977 ) and it is possible that by varying subunit combinations antigenicity could be preserved but steroid-binding properties altered. Comparative studies on the structure of uteroglobin-like molecules from different tissues will be required to solve this question.

We thank Dr M. H. Johnson for laboratory facilities and valuable suggestions and help during the preparation of the manuscript. The antiserum was prepared with the financial help of NIH Grant No.HD-05116 to Dr M. Feigelson. The work was supported by Professor Dr Dr G. Ruhenstroth-Bauer at the Max-Planck Institute of Biochemistry in Martinsried, and by a grant to Professor C. R. Austin from the Ford Foundation.

\section{References}

Arthur, A.T., Cowan, B.D. \& Daniel, J.C., JR (1972) Steroid binding to blastokinin. Fert. Steril. 23, 85-92. BeATo, M. \& BAIER, R. (1975) Binding of progesterone to proteins of uterine luminal fluid. Identification of uteroglobin as the binding protein. Biochim. biophys. Acta 392, 346-356.

Beato, M., ArnemanN, J. \& Voss, H.-J. (1977) Spectrophotometric study of progesterone binding to uteroglobin. J. Steroid Biochem. 8, 725-730.

BelER, H.M. (1968) Uteroglobin. A hormone sensitive endometrial protein involved in blastocyst development. Biochim. biophys. Acta 160, 289-291.

Davis, B.J. (1964) Disc electrophoresis. II. Method and application to human serum proteins. Ann. N. Y. Acad. Sci. 121, 404-427.

Feigelson, M., Noske, I.G., Goswami, A.K. \& Kay, E. (1977) Reproductive tract fluid proteins and their hormonal control. Ann. N. Y. Acad. Sci. 289, 273-286.
Goswami, A. \& Feigelson, M. (1974) Differential regulation of a low molecular weight protein in oviductal and uterine fluids by ovarian hormones. Endocrinology 95, 669-675.

JoHnson, M.H. (1972) The distribution of a blastokininlike uterine protein studied by immune fluorescence. Fert. Steril. 23, 929-939.

KaY, E. \& Feigelson, M. (1972) Estrogen modulated protein in rabbit oviductal fluid. Biochim. biophys. Acta 271, 436-441.

KIRCHNER, C. (1972) Immune histologic studies on the synthesis of a uterine specific protein in the rabbit and its passage through the blastocyst coverings. Fert. Steril. 23, 131-136.

KIRCHNER, C. (1976) Uteroglobin in the rabbit. I. Intracellular localization in the oviduct, uterus and preimplantation blastocyst. Cell Tiss. Res. 170, 415424. 
KRishnaN, R.S. \& Daniel, J.C., JR (1967) "Blastokinin": inducer and regulator of blastocyst development in the rabbit uterus. Science, N.Y. 158, 490-492.

McGaughey, R.W. \& Murray, F.A. (1972) Properties of blastokinin: amino acid composition, evidence for subunits, and estimation of isoelectric point. Fert. Steril. 23, 399-404.

Murray, F.A., McGaughey, R.W. \& Yarus, M.J. (1972) Blastokinin: its size, shape, and an indication of the existence of subunits. Fert. Steril. 23, 69-77.

Nieto, A., Ponstingl, H. \& Beato, M. (1977) Purification and quaternary structure of the hormonally induced protein uteroglobin. Archs Biochem. Biophys. 180, 82-92.
Noske, I.G. \& Feigelson, M. (1976) Immunologic evidence of uteroglobin (blastokinin) in the male reproductive tract and in non-reproductive ductal tissues and their secretions Biol. Reprod. 15, 704-713.

ScHwICK, H.G. (1965) Chemisch-entwicklungsphysiologische Beziehungen von Uterus zu Blastozyste des Kaninchens (Oryctolagus cuniculus). Wilhelm Roux' Arch. EntwMech. Org. 156, 283-343.

Urzua, M.A., Stambaugh, R., Flickinger, G. \& MASTROIANNI, L., JR (1970) Uterine and oviduct protein patterns in the rabbit before and after ovulation. Fert. Steril. 21, 860-865.

Received 16 March 1978 